\title{
Powoływanie Rady Ministrów w Konstytucji z 2 kwietnia 1997 r.
}

\author{
Anna Rakowska-Trela \\ Uniwersytet Łódzki, Wydział Prawa i Administracji \\ Katedra Prawa Konstytucyjnego
}

\section{Uwagi wprowadzające}

Polska Konstytucja z 2 kwietnia 1997 r. w art. 10 zalicza Radę Ministrów, obok Prezydenta Rzeczypospolitej, do organów władzy wykonawczej. Szczegółowa regulacja dotycząca Rady Ministrów znajduje się w rozdziale VI ustawy zasadniczej, obejmującym Radę Ministrów łącznie z administracją rządową (art. 146-162), a zarazem oddzielnie względem Prezydenta RP (rozdział V). Należy jednak zaznaczyć, że współcześnie „rzeczywisty charakter i rola ustrojowa władzy wykonawczej w państwie demokratycznym wykraczają poza historycznie ugruntowane traktowanie egzekutywy jako jedynie wykonawcy prawa stanowionego przez parlament, będący przedstawicielstwem suwerena, narodu"1.

Obok składu, zadań, kompetencji oraz odpowiedzialności, również sposób kreacji organu władzy publicznej jest jednym z najważniejszych elementów współokreślających jego pozycję ustrojową. Odnośnie do Rady Ministrów został on dość szczegółowo zdeterminowany przepisami Konstytucji, w tym jej art. 154 i 155. Nie sposób jednak nie odnotować, że tryb powoływania rządu jest pochodną szeregu zasad ustrojowych, w tym zasady suwerenności narodu, zasady republikańskiej formy rządów, zasady jednolitości państwa, a także zasady państwa demokratycznego oraz podziału, równowagi i współdziałania władz.

Odwołując się do historii polskiego konstytucjonalizmu, warto wskazać, że pierwsze polskie konstytucje zdecydowanie oszczędniej regulowały procedurę powoływania rządu. Zgodnie z Konstytucją marcową ${ }^{2}$ ministrowie tworzyli Radę Ministrów pod przewodnictwem Prezesa Rady Ministrów (art. 55). Prezydent Rzeczypospolitej mianował i odwoływał Prezesa Rady Ministrów, a na jego wniosek mianował i odwoływał ministrów, zaś na wniosek Rady Ministrów obsadzał

1 Zob. D. Dudek, Nota do art. 146, [w:] M. Safjan (red.), Konstytucja RP, t. II: Komentarz do art. 87-243, Warszawa 2016, uwaga $\mathrm{nr} 8$.

2 Ustawa z dnia 17 marca 1921 r. - Konstytucja Rzeczypospolitej Polskiej, Dz.U. z 1921 r., nr 44, poz. 267. 
urzędy cywilne i wojskowe, zastrzeżone w ustawach (art. 45). Liczbę, zakres działania i wzajemny stosunek ministrów, jak również kompetencje Rady Ministrów określała osobna ustawa.

Jak powszechnie wiadomo, wraz z przyjęciem Konstytucji kwietniowej w $1935 \mathrm{r}^{3}$ radykalnie zmieniła się koncepcja ustroju, od tej pory bowiem Prezydent Rzeczypospolitej stał na czele państwa i w jego osobie skupiała się jednolita i niepodzielna władza państwowa (art. 2 ust. 1 i 4), zaś organami państwa, pozostającymi pod zwierzchnictwem Prezydenta RP, były: w pierwszej kolejności rząd, następnie Sejm, Senat i inne organy (art. 3 ust. 1). Rząd składał się z Prezesa Rady Ministrów oraz ministrów (art. 25 ust. 2). Mianowanie i odwoływanie Prezesa Rady Ministrów należało do prerogatyw Prezydenta RP (art. 12 ust. 2 lit. c).

W Konstytucji Polskiej Rzeczypospolitej Ludowej przyjęto zasadę jednolitości władzy państwowej, z przewodnią rolą Sejmu PRL ${ }^{4}$. Rada Ministrów była wówczas naczelnym wykonawczym i zarządzającym organem władzy państwowej (art. 30 ust. 1). Sejm powoływał i odwoływał Rząd Polskiej Rzeczypospolitej Ludowej lub poszczególnych jego członków. W okresach między sesjami Sejmu członków Rady Ministrów na wniosek Prezesa Rady Ministrów powoływała i odwoływała Rada Państwa. Miała ona obowiązek przedstawić swoją uchwałę Sejmowi na najbliższej sesji do zatwierdzenia (art. 29).

Sytuacja radykalnie zmieniła się po przyjęciu 17 października 1992 r. ustawy konstytucyjnej o wzajemnych stosunkach między władzą ustawodawczą i wykonawczą Rzeczypospolitej Polskiej oraz o samorządzie terytorialnym ${ }^{5}$. Ten akt konstytucyjny przyjął bowiem tzw. tryb ostrożnościowy, $\mathrm{z}$ aż pięcioma możliwymi fazami postępowania ${ }^{6}, k$ tóre były uregulowane w raczej lakonicznych art. 57-60 i 62. Ponadto warto zaznaczyć, że art. 61 przewidywał, iż wniosek Prezesa Rady Ministrów dotyczący powołania ministrów spraw zagranicznych, obrony narodowej i spraw wewnętrznych premier przedstawiał po zasięgnięciu opinii Prezydenta Rzeczypospolitej.

W obecnie obowiązującej Konstytucji RP, jak już wspomniano, powoływanie Rady Ministrów uregulowane jest w art. 154 i 155, i obejmuje trzy kolejne procedury, z których każda następna przewidziana jest na wypadek niepowodzenia poprzedniej. Na wstępie analizy przywołanych przepisów warto pochylić się nad kwestiami terminologicznymi i doprecyzować, jak należy określać poszczególne, następujące po sobie, etapy konstytucyjne powoływania Rady Ministrów. Otóż, Janusz Mordwiłko pisze o „fazach procedury” lub „stadiach procedury”, sugeru-

3 Dz.U. z 1935 r., nr 30, poz. 227.

4 Art. 15 przewidywał, że najwyższym organem władzy państwowej był Sejm, który - jako najwyższy wyraziciel woli Ludu pracującego miast i wsi - urzeczywistniał suwerenne prawa narodu; Dz.U. z 1952 r., nr 33, poz. 232.

5 Dz.U. z 1992 r., nr 84 poz. 426.

6 Zob. D. Dudek, Nota do art. 146, uwaga nr 2.

7 J. Mordwitko, Opinia w sprawie aspektów prawnych wiążących się z powoływaniem i odwoływaniem rządu, „Przegląd Sejmowy” 2007, z. 5, s. 144-146. 
jąc, że procedura jest jedna i że została ona w ustawie zasadniczej podzielona na trzy fazy lub inaczej stadia. O jednej procedurze i trzech etapach wspomina także Andrzej Szmyt ${ }^{8}$. Z kolei Krzysztof Skotnicki zdaje się opowiadać za wyróżnieniem trzech konstytucyjnych procedur powoływania rządu, podzielonych wewnętrznie na etapy ${ }^{9}$. Pewną niekonsekwencję terminologiczną wykazuje natomiast Marcin Stębelski ${ }^{10}$, który wspomina o „etapach procedury”, przy czym zdaje się to pojęcie odnosić zarówno do trzech wyróżnionych konstytucyjnie procedur, jak i do ich wewnętrznych faz. Wydaje się, że najbardziej poprawne terminologicznie jest wyróżnianie trzech konstytucyjnych procedur powoływania Rady Ministrów, podzielonych na wewnętrzne fazy - jak czyni to K. Skotnicki - każda z nich bowiem tworzy odrębną, samodzielną całość, w której można wyróżnić podmiot inicjujący i kolejne czynności, których realizacja zmierza do skutecznego powołania rządu.

W procedurach powoływania rządu uczestniczą - z różnym nasileniem rzeczywistego wpływu na jej przebieg - Prezydent RP, Sejm oraz premier. Choć regulacja przyjęta w obowiązującej ustawie zasadniczej jest o wiele bardziej rozbudowana i szczegółowa od rozwiązań wcześniejszych, to jednak nie obejmuje wszystkich procesów zachodzących w procedurach powoływania rządu, w szczególności faktycznych, nieformalnych działań i decyzji o charakterze politycznym, w sposób konieczny towarzyszących kształtowaniu Rady Ministrów.

Poprzedzając szczegółowe omówienie procedur warto zaznaczyć, że każda kolejna procedura, przewidziana na wypadek niepowodzenia poprzedniej, jest ograniczona czasowo i musi zamknąć się w terminie 14 dni - podobnie jak fazy wyszczególnione przez ustrojodawcę wewnątrz kolejnych procedur. Terminy te mają charakter terminów zawitych, które w żaden sposób nie mogą zostać przedłużone ${ }^{11}$.

Ponadto warto wspomnieć, że art. 147 Konstytucji z 2 kwietnia 1997 r. określa kategorie osób wchodzących w skład Rady Ministrów, nie precyzując przy tym liczby członków rządu, tylko przewidując, jakie kategorie osób muszą wejść, a jakie mogą wchodzić do rządu. Zgodnie z art. 147 ust. 1 Konstytucji Rada Ministrów składa się z Prezesa Rady Ministrów oraz ministrów. Te dwie kategorie członków rządu muszą obligatoryjnie znaleźć się w Radzie Ministrów. Bez premiera i ministrów rząd nie może ani powstać, ani funkcjonować. Biorąc pod uwagę kategorie członków, jest to minimalny, podstawowy, a zarazem obligatoryjny skład Rady Ministrów. Ten skład może być rozszerzony o piastujących inne stanowiska, którzy już nie muszą, tylko mogą być powołani w skład Rady Ministrów. Zgodnie bowiem z art. 147 ust. 2 do rządu mogą być powołani: wiceprezesi Rady Mini-

8 A. Szmyt, Opinia w sprawie aspektów prawnych wiążących się z powoływaniem i odwoływaniem rzqdu, „Przegląd Sejmowy” 2007, z. 5, s. 155-156.

9 K. Skotnicki, Opinia w sprawie aspektów prawnych wiążących się z powoływaniem i odwoływaniem rządu, „Przegląd Sejmowy” 2007, z. 5, s. 149.

10 M. Stębelski, Opinia w sprawie aspektów prawnych wiążących się z powoływaniem i odwoływaniem rządu, „Przegląd Sejmowy” 2007, z. 5, s. 164 i n.

11 Zob. D. Dudek, Nota do art. 146, uwaga nr 2. 
strów oraz przewodniczący określonych w ustawach komitetów. Należy jednak zaznaczyć, że art. 149 ust. 1 Konstytucji RP wyróżnia dwie kategorie ministrów: po pierwsze, ministrów, którzy kierują określonymi działami administracji rządowej, a zakres ich działania określają ustawy (tzw. ministrów resortowych) oraz, po drugie, ministrów, którzy wypełniają zadania wyznaczone im przez Prezesa Rady Ministrów (tzw. ministrów bez teki). Tym samym fakultatywny skład Rady Ministrów mogą tworzyć: wiceprezesi Rady Ministrów, ministrowie bez teki i przewodniczący określonych w ustawach komitetów.

Procedura powoływania rządu początek bierze z dymisji poprzedniego gabinetu i przyjęcia tej dymisji przez Prezydenta RP. Zgodnie z art. 162 Konstytucji RP, Prezes Rady Ministrów składa dymisję Rady Ministrów na pierwszym posiedzeniu nowo wybranego Sejmu, a także w razie nieuchwalenia przez Sejm wotum zaufania dla Rady Ministrów, wyrażenia Radzie Ministrów wotum nieufności, rezygnacji Prezesa Rady Ministrów. Prezydent może odmówić przyjęcia dymisji Rady Ministrów jedynie w razie, gdy jest ona spowodowana rezygnacją premiera; we wszystkich innych przypadkach dymisję musi przyjąć. Prezydent, przyjmując dymisję Rady Ministrów, powierza jej dalsze sprawowanie obowiązków do czasu powołania nowej Rady Ministrów.

\section{Pierwsza procedura powotywania Rady Ministrów}

Pierwsza, zasadnicza procedura powoływania Rady Ministrów rozpoczyna się $\mathrm{w}$ dniu pierwszego posiedzenia nowo wybranego Sejmu lub w dniu przyjęcia dymisji poprzedniej Rady Ministrów. Od tego momentu zaczyna biec 14-dniowy termin, w którym pierwszym krokiem zmierzającym do ukonstytuowania się rządu jest obowiązek desygnowania (czyli oficjalnego wskazania, wyznaczenia) przez Prezydenta Rzeczypospolitej Prezesa Rady Ministrów, przy czym desygnacja może nastąpić jeszcze przed formalnym otwarciem pierwszej fazy procedury tworzenia rządu, a więc przede wszystkim przed dniem pierwszego posiedzenia Sejmu, gdy już znane są wyniki wyborów i układ sił w Sejmie ${ }^{12}$. Należy zaznaczyć, że Konstytucja nie ustanawia jakichkolwiek wymogów i nie zawiera żadnych wskazań, jakimi miałby się kierować Prezydent RP przy ustalaniu kandydatury przyszłego szefa rządu, czyli desygnowaniu konkretnej osoby na stanowisko premiera $^{13}$. W piśmiennictwie co do zasady zgodnie przyjmuje się, że Prezydent RP

12 Por. R. Mojak, Parlament a rząd w ustroju Trzeciej Rzeczypospolitej Polskiej, Lublin 2007, s. $196-197$.

13 Zob. D. Dudek, Nota do art. 146, uwaga nr VI.1. 
powinien uwzględniać siłę poszczególnych ugrupowań zasiadających w Sejmie i faktyczną możliwość realizacji przez nie funkcji rządzenia. Tym samym na etapie desygnowania premiera istotne znaczenie mają utrwalone zwyczaje konstytucyjne oraz wskazania kultury politycznej, które nakazują Prezydentowi Rzeczypospolitej uwzględniać faktyczny układ sił politycznych w Sejmie. Postuluje się wprost, aby w warunkach istnienia wyraźnej i stabilnej większości jednopartyjnej lub koalicyjnej w Sejmie zwrócił się do niej o zasugerowanie kandydata ${ }^{14}$. Dopiero wobec braku konsolidacji w izbie Prezydent zachowuje większą swobodę w desygnowaniu premiera. Słusznie wiąże się to z przypisywaną Prezydentowi RP funkcją arbitrażu politycznego, wymagającego nie konkurencji, lecz współdziałania Sejmu i Prezydenta $\mathrm{w}$ procesie tworzenia rządu ${ }^{15}$.

Rola osoby desygnowanej na stanowisko premiera sprowadza się - zgodnie z art. 154 ust. 1 - do zaproponowania Prezydentowi Rzeczypospolitej składu personalnego nowej Rady Ministrów. W związku z posłużeniem się przez ustrojodawcę terminem „propozycja” (desygnowany premier „proponuje skład Rady Ministrów") należy wnosić, że Prezydent RP ma kompetencję do skorzystania lub nie z przedstawionej propozycji. Jednakże jeżeli Prezydent zdecyduje się propozycję tę zaakceptować, to może ją przyjąć jedynie w całości (en bloc $)^{16}$, natomiast wykluczyć należy dokonywanie przez głowę państwa modyfikacji składu zaproponowanego gabinetu. Na takim stanowisku stał m.in. Wojciech Sokolewicz, który wskazywał, że Prezydent RP „W zasadzie całkowicie swobodnie - może rząd powołać lub nie powoływać [...]; nie może natomiast traktować propozycji selektywnie, a zwłaszcza wprowadzać do RM osób nieproponowanych przez desygnowanego premiera" ${ }^{17}$. Jego zdaniem Prezydent może odrzucić całkowicie propozycję desygnowanego premiera, może też w konsekwencji przyjąć jego rezygnację z dalszej misji i desygnować inną osobę, a nawet „może też z własnej inicjatywy odwołać desygnowanego premiera i desygnować na jego miejsce kogoś innego"18.

W tym miejscu warto wspomnieć, że porównując rolę głowy państwa w obu fazach procedury zasadniczej, Dariusz Dudek podkreśla, że „akceptacja dużej swobody, a nawet pewnego aktywizmu Prezydenta RP w tej fazie tworzenia rządu nie uchyla jednak praktycznych trudności prawnych, dotyczących choćby trybu przyjmowania przez głowę państwa rezygnacji bądź odwołania desygnowanego premiera". Zaznacza jednocześnie, że

zakres „swobody” Prezydenta nie jest i nie może być identyczny w odniesieniu do wszystkich jego uprawnień [...]. O ile zatem Konstytucja dopuszcza implicite niepowodzenie mi-

14 L. Garlicki, Polskie prawo konstytucyjne, Warszawa 2014, s. 269.

15 D. Dudek, Nota do art. 146, uwaga nr VI.1.

16 Podobnie jak Sejm w późniejszym głosowaniu nad wotum zaufania dla całego rządu.

17 W. Sokolewicz, Nota do artykułu 154, uwaga nr 5, [w:] L. Garlicki (red.), Konstytucja Rzeczypospolitej Polskiej. Komentarz, t. 1, Warszawa 1999, s. 11.

18 W. Sokolewicz, Nota do artykułu 154, uwaga nr 5, s. 12. 
sji desygnowanego premiera [...], o tyle nie upoważnia Prezydenta do wywołania kryzysu politycznego poprzez zupełne zaniechanie desygnacji premiera. Taka nieusprawiedliwiona bezczynność głowy państwa nie tylko godziłaby w autorytet Prezydenta, stanowiąc zaprzeczenie jego ustrojowej funkcji gwaranta ciągłości władzy państwowej, ale nawet wyczerpywałaby znamiona deliktu konstytucyjnego.

\section{Jednocześnie za nieprzekonujący autor ten uznaje}

ewentualny kontrargument, oparty na regule a maiori, iż skoro Prezydent może cofnąć umocowanie desygnowanemu premierowi, a nawet odmówić (premierowi) powołania proponowanego przezeń składu rządu, może też całkowicie zaniechać aktu desygnacji. Konstytucja formułuje terminowy obowiązek Prezydenta dokonania desygnacji, czyli otwarcia procedury prowadzącej w zamierzeniu do efektywnego wyłonienia rządu. Faza pierwsza jest zatem obligatoryjna, choć nie musi wejść w stadium finalne (głosowania nad wotum zaufania).

W konsekwencji Prezydent nie może jej „pominąć” i przejść do drugiej procedury, oddając inicjatywę w ręce Sejmu ${ }^{19}$.

Prezydent Rzeczypospolitej powołuje Prezesa Rady Ministrów wraz z pozostałymi członkami Rady Ministrów w ciągu 14 dni od dnia pierwszego posiedzenia Sejmu lub przyjęcia dymisji poprzedniej Rady Ministrów i odbiera przysięgę od członków nowo powołanej Rady Ministrów (druga faza pierwszej procedury, art. 154 ust. 1 in fine). Następnie nowo powołany Prezes Rady Ministrów, w ciągu 14 dni od dnia powołania przez Prezydenta Rzeczypospolitej, przedstawia Sejmowi program działania Rady Ministrów z wnioskiem o udzielenie jej wotum zaufania. Wotum zaufania Sejm uchwala bezwzględną większością głosów w obecności co najmniej połowy ustawowej liczby posłów (trzecia faza pierwszej procedury).

Regulamin Sejmu w art. 112 precyzuje, że w debacie nad programem działania i wnioskiem o udzielenie wotum zaufania Radzie Ministrów powołanej przez Prezydenta Rzeczypospolitej w trybie art. 154 ust. 1 Konstytucji RP, przedstawionymi przez Prezesa Rady Ministrów, Marszałek Sejmu, poza kolejnością mówców zapisanych do głosu, udziela głosu wyłącznie Prezesowi Rady Ministrów. Po wyczerpaniu listy mówców i zadaniu pytań głos może zabrać wyłącznie Prezes Rady Ministrów. Marszałek Sejmu poddaje pod głosowanie wniosek Prezesa Rady Ministrów. Inne wnioski w tej sprawie są niedopuszczalne.

Niepowodzenie pierwszej, podstawowej procedury tworzenia rządu może wynikać z różnych przyczyn, począwszy od niezachowania konstytucyjnych terminów, poprzez odmowę powołania rządu przez Prezydenta, aż po brak uzyskania przez powołany i zaprzysiężony rząd wotum zaufania ze strony Sejmu. Takie sytuacje powodują uruchomienie drugiej, a pierwszej „rezerwowej” procedury powoływania Rady Ministrów. Jak wspomniano, jedyne, co nie powinno się zdarzyć, to zaniechanie desygnowania Prezesa Rady Ministrów przez Prezydenta RP. 


\section{Druga procedura powoływania Rady Ministrów}

Konstytucja przewiduje, że we wskazanych przypadkach, tj. w razie niepowołania Rady Ministrów w opisany sposób lub nieudzielenia jej wotum zaufania, Sejm w ciągu 14 dni wybiera Prezesa Rady Ministrów oraz proponowanych przez niego członków Rady Ministrów bezwzględną większością głosów w obecności co najmniej połowy ustawowej liczby posłów. Prezydent Rzeczypospolitej powołuje tak wybraną Radę Ministrów i odbiera przysięgę od jej członków (art. 154 ust. 3). Przy wyborze premiera izba działa według swojego uznania i własnej oceny. Konstytucja nie przewiduje exposé premiera.

Przepisy nie rozstrzygają jednoznacznie przebiegu i liczby głosowań. Zważywszy, że całość pierwszej z „rezerwowych” procedur powoływania rządu ma się zamknąć w terminie 14 dni, należy postulować, by już zgłoszony, a jeszcze „nieprzegłosowany" kandydat na premiera podjął działania w kierunku utworzenia składu Rady Ministrów. Z drugiej strony, zgodnie z brzmieniem art. 154 ust. 3 Konstytucji, Sejm powinien dokonać wyboru składu rządu, czyli jego członków, proponowanych przez Prezesa Rady Ministrów, a nie przez kandydata na to stanowisko. To przemawia za przeprowadzeniem dwóch głosowań, które jednak powinny być objęte porządkiem obrad jednego posiedzenia Sejmu, stanowiąc dwa kolejne punkty: wybór premiera i następnie, na jego wniosek, wybór członków Rady Ministrów. Oba akty głosowania objęte są także identycznymi wymogami formalnymi (co do quorum i większości), a co oczywiste, niepowodzenie któregokolwiek z nich uniemożliwia dokonanie przez Prezydenta Rzeczypospolitej aktu powołania rządu wobec braku wyboru przez Sejm całej Rady Ministrów. Na dwuaktowość głosowania w tej procedurze wskazują przepisy Regulamin Sejmu (art. 113) uszczegóławiające w tym zakresie Konstytucję w ten sposób, że w razie niepowołania Rady Ministrów przez Prezydenta RP w trybie podstawowym albo nieudzielenia przez Sejm powołanej Radzie Ministrów wotum zaufania na tym etapie, kandydata na Prezesa Rady Ministrów może zgłosić co najmniej 46 posłów. Termin zgłaszania kandydatur na Prezesa Rady Ministrów wyznacza Marszałek Sejmu po zasięgnięciu opinii Konwentu Seniorów. Sejm wybiera Prezesa Rady Ministrów w głosowaniu imiennym. Regulamin przewiduje dalej, że Prezes Rady Ministrów przedstawia Sejmowi na posiedzeniu program działania rządu (warto przypomnieć, że takiego wymogu nie ustanawia Konstytucja) oraz proponowany przez niego skład Rady Ministrów. Wniosek Prezesa Rady Ministrów w sprawie wyboru Rady Ministrów jest głosowany łącznie, en bloc. Marszałek Sejmu poddaje pod głosowanie wniosek Prezesa Rady Ministrów. Inne wnioski w tej sprawie są niedopuszczalne. Uchwałę o wyborze Rady Ministrów Marszałek Sejmu przekazuje niezwłocznie Prezydentowi Rzeczypospolitej. 
Należy zaznaczyć, że mimo iż Konstytucja wprost odnosi zakreślony w drugiej procedurze 14-dniowy termin wyłącznie do działań Sejmu ${ }^{20}$ polegających na wybraniu Prezesa oraz proponowanych przez niego członków Rady Ministrów, nie obejmując wyraźnie działań Prezydenta RP sprowadzających się do powołania tak wybranej Rady Ministrów i odebrania przysięgi od jej członków, to należy przyjąć, że termin 14-dniowy odnosi się łącznie do wszystkich czynności proceduralnych $\mathrm{w}$ ramach analizowanej procedury, podejmowanych przez wszystkie uczestniczące w niej organy aż do momentu zaprzysiężenia nowego rządu. Tylko taka interpretacja pozwala bowiem ustalić końcowy moment drugiej procedury, będący przecież jednocześnie potencjalnym początkiem biegu terminu ostatniej, trzeciej z procedur tworzenia rządu. Przeciwna wykładnia powodowałaby, że Prezydent, niezadowolony z wyboru dokonanego przez Sejm, a niezwiązany jakimkolwiek terminem, mógłby dowolnie długo opóźniać powołanie i przejęcie obowiązków przez nową Radę Ministrów i tym samym przedłużać działanie poprzedniego rządu.

Tak wyłoniona Rada Ministrów może być określona jako swoisty „rząd parlamentarny" ${ }^{21} \mathrm{z}$ uwagi na brak wpływu Prezydenta Rzeczypospolitej na jego skład, poza uprawnieniami formalnymi, czysto nominacyjnymi. Prezydent ma bowiem obowiązek powołania Rady Ministrów wybranej przez Sejm w drugiej procedurze i odebrania przysięgi od jej członków.

\section{Trzecia procedura powoływania Rady Ministrów}

W wypadku niepowodzenia drugiej procedury tworzenia rządu (parlamentarnego) Konstytucja przewiduje obligatoryjne uruchomienie trzeciej i ostatniej z nich, swoistej „awaryjnej” procedury, która w istocie jest uproszczonym, nie całkiem analogicznym, wariantem pierwszej procedury tworzenia Rady Ministrów. W jej toku, w razie niepowołania Rady Ministrów w trybie art. 154 ust. 3, Prezydent Rzeczypospolitej w ciągu 14 dni powołuje Prezesa Rady Ministrów i na jego wniosek pozostałych członków Rady Ministrów oraz odbiera od nich przysięgę. Sejm w ciągu 14 dni od dnia powołania Rady Ministrów przez Prezydenta Rzeczypospolitej udziela jej wotum zaufania większością głosów w obecności co najmniej połowy ustawowej liczby posłów. Procedura ta rozpoczyna się zatem z dniem, w którym Sejm nie zdołał wybrać premiera i proponowanego przezeń składu przed upły-

20 „Sejm w ciągu 14 dni od upływu terminów określonych w ust. 1 lub ust. 2 wybiera Prezesa Rady Ministrów oraz proponowanych przez niego członków Rady Ministrów bezwzględną większością głosów w obecności co najmniej połowy ustawowej liczby posłów. Prezydent Rzeczypospolitej powołuje tak wybraną Radę Ministrów i odbiera przysięgę od jej członków".

21 L. Garlicki, Polskie prawo..., s. 287. 
wem 14-dniowego terminu lub w razie bezskutecznego upływu tego konstytucyjnego terminu ${ }^{22}$.

Prezydent w ciągu 14 następnych dni, po negatywnym zakończeniu drugiej procedury, powołuje nowego Prezesa Rady Ministrów i na jego wniosek pozostałych członków Rady Ministrów oraz odbiera od nich przysięgę. Z tą chwilą ustaje tymczasowe pełnienie obowiązków dotychczasowego rządu. Natomiast Sejm w ciągu 14 dni od daty powołania przez Prezydenta Rzeczypospolitej udziela Radzie Ministrów wotum zaufania, do czego wymagana jest tylko zwykła większość głosów przy 50\% quorum (art. 155 ust. 1). Co oczywiste, dla uzyskania takiej większości wystarczy jakakolwiek przewaga głosujących za wotum zaufania w stosunku do głosujących przeciw; przy jej ustalaniu nie uwzględnia się głosów wstrzymujących się.

Konstytucja RP nie przewiduje $\mathrm{w}$ tej procedurze etapu desygnowania premie$\mathrm{ra}^{23}$, nadrzędnym celem staje się tu bowiem zapewnienie efektywności działania rządowi, dlatego też Prezydent jest zobligowany do powołania premiera i na jego wniosek Rady Ministrów, co dopiero umożliwia podjęcie przez nowy gabinet próby realizacji ostatniego stadium ostatniej procedury w Sejmie. Przyjmuje się więc, że w tej ostatniej, trzeciej procedurze Prezydent RP nie może zaniechać ani odmówić powołania rządu, natomiast przewidziane w Konstytucji skrócenie kadencji Sejmu stanowi prawo i obowiązek głowy państwa wyłącznie w razie nieudzielania przez Sejm wotum zaufania de facto i de iure powołanej Radzie Ministrów.

Podobnie jak w procedurze pierwszej, tak też w ostatniej przepisy Konstytucji RP nie determinują doboru przez głowę państwa osoby powoływanej na premiera. Wydaje się, że w tej procedurze Prezydent Rzeczypospolitej posiada nawet większą swobodę: po pierwsze dlatego, że powołanemu przezeń rządowi wystarczy przecież poparcie zwykłej większości posłów; po drugie, ugrupowania polityczne w Sejmie muszą skalkulować „opłacalność” nieudzielania Radzie Ministrów wotum zaufania ze skutkiem takiego posunięcia w postaci skrócenia kadencji izb. Niewykluczone więc, że Prezydent RP powoła na stanowisko premiera nawet osobę nieskutecznie desygnowaną w pierwszej fazie lub kandydującą bez powodzenia na to stanowisko w fazie drugiej.

Działanie Prezydenta Rzeczypospolitej związane z kreacją Rady Ministrów w trzeciej procedurze ma wyraźnie przebieg dwuetapowy, choć zamyka się w jednym 14-dniowym terminie. Otóż, Prezydent RP najpierw powołuje Prezesa Rady Ministrów, a na-

22 W polskiej praktyce parlamentarnej okresu III RP zdarzyło się tylko raz, że Sejm w ogóle nie przystąpił do wyłonienia rządu parlamentarnego w drugiej procedurze (kazus rządu premiera M. Belki w 2004 r.). Wobec tego „zaniechania” sejmowego Prezydent RP powołał w procedurze trzeciej na urząd premiera tę samą osobę, która była desygnowana w ramach bezskutecznej fazy pierwszej, a Sejm zaakceptował jej gabinet.

23 Zob. W. Skrzydło, [w:] W. Skrzydło (red.), Polskie prawo konstytucyjne, Lublin 2001, s. 358; przeciwny pogląd, upatrujący w tej fazie trzech analogicznych stadiów: desygnowania premiera, powołania rządu, uzyskania sejmowego wotum zaufania, prezentuje R. Mojak, Parlament a rzq̨d w ustroju..., s. 199 i n. 
stępnie na jego wniosek pozostałych członków Rady Ministrów. Prezydent nie może kontestować wniosku w zakresie składu Rady Ministrów. Nieprzypadkowo Konstytucja w tym miejscu nie stanowi o - jak było to w procedurze pierwszej - „proponowaniu" składu, ale o wniosku Prezesa Rady Ministrów. Zatem niewykluczone, że mogłoby się zdarzyć, iż głowa państwa byłaby obowiązania uwzględnić wniosek premiera nawet wbrew sugestiom, a nawet wyraźnie sformułowanym własnym życzeniom.

\section{Charakter terminów w ramach procedur powoływania Rady Ministrów}

$\mathrm{W}$ dotychczasowej praktyce oraz $\mathrm{w}$ nauce prawa największe wątpliwości budzi charakter 14-dniowych terminów, przewidzianych przez ustrojodawcę dla realizacji kolejnych faz i procedur powoływania Rady Ministrów. Nie budzi wątpliwości to, że terminy te - jak już wcześniej wspomniano - mają charakter zawity (prekluzyjny). Ich niedochowanie powoduje zamknięcie jednej procedury lub fazy powoływania rządu i przejście do kolejnej, mają więc one "dyscyplinujący" charakter ${ }^{24}$. Dyskusyjne jest natomiast, czy stwierdzenie „od upływu terminów określonych w ust. 1 lub ust. 2” (art. 154 ust. 3) oznacza, że w każdym przypadku nakazuje czekać na upływ pełnych 14 dni dla podjęcia następnego działania. Należy od razu zaznaczyć, że w piśmiennictwie dominująca jest teza o niemożliwości skracania terminów zawartych w art. 154 Konstytucji. Na takim stanowisku stanął Leszek Garlicki, pisząc, że „nie ma prawnych przeszkód, by w ramach 14-dniowego terminu prezydent desygnował kolejno dwie lub nawet więcej osób na stanowisko premiera”, czy odnosząc się do procedury z art. 154 ust. 3, że „nieuzyskanie bezwzględnej większości głosów bądź odrzucenie wniosku premiera przez Sejm nie wyklucza podejmowania kolejnych prób wyłonienia rządu sejmowego, choć w praktyce termin 14 dni może okazać się za krótki dla powtórzenia całej procedury od początku"25. Na podobnym stanowisku stanęli Krzysztof Skotnicki ${ }^{26}$, a także Andrzej Szmyt, który wskazuje, że „w sytuacji bezczynności organu konieczne jest jednak odczekanie pełnych 14 dni z przewidzianych terminów, a z ich upływem - jak wspomniano - zamyka się dany etap i otwiera się etap następny"27. Przeciwnego zdania w zasadzie jest jedynie J. Mordwiłko, który argumentuje, że

24 A. Szmyt, Opinia w sprawie aspektów prawnych..., s. 156.

25 L. Garlicki, Rada Ministrów: powoływanie - kontrola - odpowiedzialność, [w:] A. Bałaban (red.), Rada Ministrów - organizacja i funkcjonowanie, Kraków 2002, s. 126 i 134.

26 K. Skotnicki, Opinia w sprawie aspektów prawnych..., s. 151 i 153

27 A. Szmyt, Opinia w sprawie aspektów prawnych..., s. 156. Podobnie także: S. Patyra, Prawnoustrojowy status Prezesa Rady Ministrów w świetle Konstytucji z 2 kwietnia 1997 r., Warszawa 2002, s. 36. 
Konstytucja (art. 154 i 155) nie wskazuje, aby podmiot ten [podmiot inicjujący - przyp. A. R.-T.] miał możliwość wielokrotnego działania w ramach stadium. Idzie nie tylko o sprawne powoływanie rządu, bez przeciągania procedury (i tak są to trzy dość rozwlekłe stadia), ale o jasność i czytelność procedury dla opinii publicznej. Wyborcy nie mogą być wprowadzani w konfuzję procedurą nieczytelną, rodzącą przekonanie o manipulowaniu nimi. Organy konstytucyjne muszą mieć świadomość, iż wymóg praworządności polega na tym, aby ich decyzje były jednoznaczne ze zdeterminowaną odpowiedzialnością, a nie podejmowane „na próbę”, czy też z nieczytelną intencją gry z przeciwnikami politycznymi. Postrzeganie możliwości podejmowania wielokrotnych decyzji w ramach stadium niezwykle komplikuje odczytanie i tak sprawiających kłopot terminów zawartych w art. 154 i 155 Konstytucji. Tytułem przykładu - jeżeli przyjmiemy, że prezydent w pierwszym formowaniu rządu ma 14 dni na powołanie premiera i może tę czynność powtórzyć kilkakrotnie, to powstaje pytanie, od jakiego terminu liczyć14 dni, o których mowa w art. 154 ust. 2 Konstytucji. Przepis art. 154 ust. 2 Konstytucji stanowi, iż prezes Rady Ministrów w ciągu 14 dni „od dnia powołania” przez prezydenta przedstawia program działania rządu wraz z wnioskiem o wotum zaufania. Jeżeli prezydent poprowadziłby swoistą grę ustrojową i dopiero np. trzeci rząd przez niego powołany w ciągu przysługujących prezydentowi 14 dni przedstawiłby Sejmowi program i wniosek o wotum zaufania, to czy 14 dni na przedstawienie tego programu należałoby liczyć od pierwszego powołanego rządu prezydenckiego czy np. trzeciego - powołanego w trzynastym dniu przez prezydenta? Jeżeli od pierwszego rządu powołanego przez prezydenta, np. w pierwszym dniu okresu 14-dniowego, to byłoby nielogiczne, aby 14 dni na przedstawienie programu Sejmowi miał rząd, którego przez 12 dni nie było, jeżeli zaś 14 dni policzyć od rządu utworzonego w trzynastym dniu okresu 14-dniowego (co byłoby zasadne merytorycznie i logiczne), to prezydent uzyskałby nieprzewidziany Konstytucją dodatkowy okres na powoływanie rządu w tzw. pierwszym stadium ${ }^{28}$.

Poszukiwanie na tak postawiony problem wskazówek w praktyce ustrojowej jest trudne. Można jednak przywołać sytuację z 2004 r., gdy to 14 maja 2004 r. Sejm nie udzielił premierowi Markowi Belce wotum zaufania w pierwszej procedurze tworzenia rządu, co spowodowało wcześniejsze otwarcie drugiej procedury tworzenia rządu. Sejm jednak w ciągu wyznaczonego konstytucyjnie 14-dniowego terminu nie podjął próby stworzenia gabinetu. Opisany przebieg pierwszej procedury tworzenia tego rządu wskazuje więc, że podjęcie przez właściwy organ uczestniczący w kreacji rządu zakończonej niepowodzeniem czynności w ramach tej procedury przerywa bieg terminu i powoduje przejście do kolejnej procedury. Niemniej jednak wydaje się, że bardziej racjonalne jest jednak stanowisko W. Sokolewicza, K. Skotnickiego, a także A. Szmyta, którzy dostrzegają potrzebę „wyczekania” do momentu zakończenia biegu terminu. 


\section{Zakończenie}

Polski ustrojodawca w Konstytucji z 1997 r. szczegółowo uregulował procedurę powoływania Rady Ministrów. Tym niemniej nawet drobiazgowa regulacja nie uchroniła od wątpliwości interpretacyjnych. Choć co do zasady kreacja rządu nie powoduje w praktyce ustrojowej problemów, zdarzały się przypadki, w których stosowanie niektórych przepisów zawartych w art. 154 i 155 ustawy zasadniczej rodziło problemy. Oceniając omawianą regulację, należy wskazać, że współangażuje ona w proces powoływania rządu dwa główne podmioty, tj. większość parlamentarną oraz prezydenta, przyznając im - w zależności od etapu i układu politycznego - silniejsze lub słabsze kompetencje i stwarzając warunki do zapewnienia minimum porozumienia w zakresie kreacji organu prowadzącego bieżącą politykę państwa.

\section{Santrauka}

\section{7 m. balandžio 2 d. Konstitucijos nustatyta Ministrų Tarybos skyrimo tvarka}

1997 m. balandžio 2 d. Lenkijos Konstitucijos 10 str. priskiria Ministrų Tarybą, kaip ir Lenkijos Respublikos Prezidentą i vykdomosios valdžios organus. Su Ministrų Tarybos skyrimu susijusi tvarka yra smulkmeniškai išdèstyta VI Pagrindinio įstatymo skyriuje, kuris apima Ministrų Tarybą kartu su vyriausybès administracija (146-162 str.) ir taip pat atskirai aptaria jų sąryši su Prezidentu (V skyrius).

Be sudèties, užduočių, kompetencijų bei atsakomybės, taip pat ir valstybės valdžios institucijos skyrimo būdas, tai vienas iš svarbiausių elementų, kurie apibrèžia jos poziciją politinėje valstybès sistemoje. Ministrų Tarybos skyrimas yra gan smulkmeniškai apibrèžtas Konstitucijos nuostatose, ypač 154 ir 155 straipsniuose. Tačiau negalima nepaminèti, kad vyriausybès skyrimo tvarka yra visos eilès sisteminių principų išvestiné, tokių kaip tautos suvereniteto principas, respublikine valdymo forma, valstybès vieningumo principas, o taip pat demokratinès valstybės tvarka, o taip pat valdžios pagal kompetencijas pasidalijimas, pusiausvyra ir organų sąveika.

Vyriausybès kūrimas apima tris eilines procedūras, iš kurių kiekviena paskesnè yra numatyta atvejui, kai ankstesné nebuvo sèkminga. Pirmoje procedūroje pirmiausiai Prezidentas paskiria Ministrų Tarybos pirmininką, kuris siūlo Ministrų Tarybos sudètị. Prezidentas paskiria Ministrų Tarybos pirmininką kartu su likusiais Ministrų Tarybos nariais per 14 dienų nuo pirmojo Seimo posėdžio arba nuo ankstesnès Vyriausybès atsistatydinimo dienos ir priima naujai paskirtos Ministrų Tarybos narių priesaiką. Premjeras per 14 dienų nuo dienos, kada Prezidentas ji paskyrè, pateikia Seimui Ministrų Tarybos veiklos programą, kviesdamas pareikšti jai pasitikèjimą. Pasitikèjimą Seimas priima absoliučia balsų dauguma, balsavime dalyvaujant ne mažiau kaip pusei ịstatymu nustatytų Seimo narių. 
Jeigu aukščiau aprašyta tvarka Ministrų Tarybos sudaryti nepavyks arba jeigu pirmoje procedūroje nebus išreikštas pasitikejimas, prasideda antroji procedūra, kurioje Seimas per 14 dienų nuo pasibaigusių terminų išrenka Ministrų Tarybos pirmininką bei jo siūlomus Ministrų Tarybos narius absoliučia balsų dauguma, balsavime dalyvaujant ne mažiau kaip pusei įstatymu nustatytų Seimo narių. Prezidentas skiria tokiu būdu išrinktą Ministrų Tarybą ir priima jos narių priesaiką.

Trečioje procedūroje, t. y. jeigu Ministrų Tarybos sudarymas aukščiau aprašytu būdu nepasisekè, Prezidentas 14 dienų terminu skiria Premjerą ir pagal jo pasiūlymą likusius Ministrų Tarybos narius, bei priima jų priesaiką. Seimas per 14 dienų nuo dienos, kada Prezidentas skyrè Ministrų Tarybą, suteikia jai pasitikejimą absoliučia balsų dauguma, balsavime dalyvaujant ne mažiau kaip pusei įstatymu nustatytų Seimo narių. Jeigu šiame etape pasitikejimas Ministrų Tarybai nebus suteiktas, Prezidentas sutrumpina Seimo kadenciją ir išduoda potvarkị dẻl rinkimų i naują Seimą organizavimo.

\section{Literatura}

Garlicki L., Konstytucja Rzeczypospolitej Polskiej. Komentarz, t. 1, Warszawa 1999.

Garlicki L., Rada Ministrów: powoływanie - kontrola - odpowiedzialność, [w:] A. Bałaban (red.), Rada Ministrów - organizacja i funkcjonowanie, Kraków 2002.

Mojak R., Parlament a rząd w ustroju Trzeciej Rzeczypospolitej Polskiej, Lublin 2007.

Mordwiłko J., Opinia w sprawie aspektów prawnych wiążacych się z powoływaniem i odwoływaniem rządu, „Przegląd Sejmowy” 2007, z. 5.

Patyra S., Prawnoustrojowy status Prezesa Rady Ministrów w świetle Konstytucji z 2 kwietnia 1997 r. Warszawa 2002.

Safjan M. (red.), Konstytucja RP, t. 2, Warszawa 2016.

Skotnicki K., Opinia w sprawie aspektów prawnych wiążących się z powoływaniem i odwoływaniem rządu, „Przegląd Sejmowy” 2007, z. 5.

Skrzydło W. (red.), Polskie prawo konstytucyjne, Lublin 2001.

Stębelski M., Opinia w sprawie aspektów prawnych wiążacych się z powoływaniem i odwoływaniem rządu, „Przegląd Sejmowy” 2007, z. 5.

Szmyt A., Opinia w sprawie aspektów prawnych wiążacych się z powolywaniem i odwolywaniem rzadu, „Przegląd Sejmowy” 2007, z. 5.

\section{Akty prawne}

Ustawa z dnia 17 marca 1921 r. - Konstytucja Rzeczypospolitej Polskiej, Dz.U. z 1921 r., nr 44, poz. 267.

Ustawa Konstytucyjna z dnia 23 kwietnia 1935 r., Dz.U. z 1935 r., nr 30 poz. 227.

Konstytucja Polskiej Rzeczypospolitej Ludowej uchwalona przez Sejm Ustawodawczy w dniu 22 lipca 1952 r., Dz.U. z 1952 r., nr 33, poz. 232. 
Ustawa Konstytucyjna z 17 października 1992 r. o wzajemnych stosunkach między władzą ustawodawczą i wykonawczą Rzeczypospolitej Polskiej oraz o samorządzie terytorialnym, Dz.U. z 1992 r., nr 84, poz. 426.

Konstytucja Rzeczypospolitej Polskiej z dnia 2 kwietnia 1997 r., Dz.U. z 1997 r., nr 78, poz. 483. 